\title{
Begrundelser for ytringsfriheden og dens grænser ${ }^{1}$
}

Hvilke grunde er der til at have ytringsfrihed og bestemte begrænsninger heraf? De officielle begrundelser for blasfemi- og racismeparagrafferne skitseres, hvorefter tre overordnede begrundelser for ytringsfriheden undersøges med henblik på, om de tillader begrænsninger herpå. Derpå diskuteres det såkaldte skadesprincip, der ofte antages at udelukke den type begrænsninger af ytringsfriheden, som $\mathrm{fx}$ findes i racismeparagraffen. Skadesprincippet udelukker dog ikke sådanne begrænsninger, men en fuld retfærdiggørelse af dem kræver en bredere begrundelse, og anerkendelse af minoriteters ligeværd diskuteres som et bud på en sådan. På denne baggrund diskuteres sagen om Muhammedtegningerne og Rigsadvokatens afvisning af at rejse sag mod Fyllands-Posten i forhold til racismeparagraffen.

En udbredt holdning under debatterne om Fyllands-Postens Muhammedtegninger var, at i Danmark er der ytringsfrihed uden noget „men“. Mange hævdede, at ytringsfriheden er absolut og ikke fx kan begrænses af „særlige“ hensyn til religiøse følelser eller mindretal (Rose, 2005). Som mange jurister har påpeget, er dette faktuelt forkert (Koch, 2006: 80; Rigsadvokaten, 2006a: 34; Thorsen, 2006: 79-83). Grundlovens $\$ 77$ forbyder statslig censur, men tillader begrænsninger af ytringsfriheden via lovgivning. Regeringen eller politiet kan ikke gribe ind over for enkeltytringer efter forgodtbefindende, men Folketinget kan vedtage love, der begrænser ytringsfriheden, som ytringer efterfølgende kan prøves i forhold til ved domstolene. Der er en mængde gældende og for de fleste at se rimelige love, der begrænser og kriminaliserer injurier, foragt for retten, afsløring af statshemmeligheder, falsk vidnesbyrd, dokumentfalsk, markedsføring, brud på ophavsret, tavshedspligt osv. I forbindelse med ytringer som Muhammedtegningerne er to retsregler dog særlig relevante, nemlig straffelovens $\$ 140$, den såkaldte „blasfemiparagraf“, og $\$ 266$ b, den såkaldte „racismeparagraf" (Rigsadvokaten, 2006a). ${ }^{2}$

Men ét er den faktiske retstilstand, noget andet er, hvordan retstilstanden bør være. Udsagnene om ytringsfrihedens absolutte status kan være foreskrivende i sidstnævnte henseende frem for beskrivende i førstnævnte henseende. Så er der tale om normative udsagn om, at ytringsfriheden bør være ubegrænset, eller i det konkrete eksempel nok nærmere at ytringsfriheden ikke bør begrænses af hensyn til religiøse følelser eller mindretal, hvorfor blasfemiog racismeparagrafferne bør afskaffes. Dette er da også blevet hævdet. Fx fremsatte Dansk Folkeparti allerede før sagen om Muhammedtegningerne lovfor- 
slag om afskaffelse af begge paragraffer ${ }^{3}$ og har for nylig genfremsat lignende forslag. ${ }^{4}$

Spørgsmålet er, hvilke grunde der på den ene side er til at have ytringsfrihed, dvs. en særlig, om end ikke nødvendigvis absolut, beskyttelse af ytringer (Schauer, 1982: 7f.; Barendt, 2005: 7; Brison, 1998: 320)5 , og på den anden til at have bestemte begrænsninger heraf. Hermed flyttes diskussionen fra det juridiske spørgsmål om den positive retstilstand til det moralfilosofiske eller politisk filosofiske om, hvordan retstilstanden bør være. I forhold til sagen om Muhammedtegningerne ændres spørgsmålet tilsvarende fra, om publikationen var ulovlig (Rigsadvokaten, 2006a; Koch, 2006), til om den burde være det, hvilket er en øvelse inden for anvendt etik eller politisk filosofi (Lægaard, 2007b; Post, 2007).

Denne artikel omhandler disse normative spørgsmål. Efter en skitse af de officielle rationaler for blasfemi- og racismeparagrafferne undersøges tre overordnede begrundelser for ytringsfriheden med henblik på, om de tillader begrænsninger herpå. Derefter diskuteres det såkaldte skadesprincip, der dels er fremtrædende i debatter om ytringsfrihed, dels ofte antages at udelukke den type begrænsninger af ytringsfriheden, som $\mathrm{fx}$ findes i racismeparagraffen. Skadesprincippet udelukker ikke sådanne begrænsninger, men en fuld retfærdiggørelse af dem kræver en bredere begrundelse, og beskyttelse af minoriteters ligeværd præsenteres og diskuteres som en mulig kandidat. Afslutningsvis diskuteres sagen om Muhammedtegningerne og Rigsadvokatens afvisning af at rejse sag mod Fyllands-Posten i forhold til racismeparagraffen på baggrund af de behandlede begrundelser.

\section{Racismeparagraffen}

„\$266 b. Den, der offentligt eller med forsæt til udbredelse i en videre kreds fremsætter udtalelser eller anden meddelelse, ved hvilke en gruppe af personer trues, forhånes eller nedværdiges pga. sin race, hudfarve, nationale eller etniske oprindelse, tro eller seksuelle orientering, straffes med bøde eller fængsel indtil 2 år. Stk. 2. Ved straffens udmåling skal det betragtes som en særligt skærpende omstændighed, at forholdet har karakter af propagandavirksomhed.“

Denne paragraf blev oprindelig indført i 1939 som svar på nazistisk jødeforfølgelse. Begrundelsen var behovet for beskyttelse af udsatte grupper ud over den, der sikres af injurieparagraffen, dvs. beskyttelse af grupper som grupper. I 1971 blev paragraffen ændret til den nuværende ordlyd (undtagen tilføjelsen om seksuel orientering, som kom til i 1987, og stk. 2 fra 1995) for at leve op til FN's racediskriminationskonvention fra 1965, så formålet nu endvidere var at bekæmpe enhver tilskyndelse til eller udøvelse af racediskrimination (Rigsadvokaten, 2006a: 16-19; Koch, 2006: 75f; IFM, 2006). 
Den populære betegnelse „racismeparagraffen“ er vildledende, da racistiske ytringer ikke nødvendigvis opfylder bestemmelsens grovhedskriterium (Rigsadvokaten, 2006a: 20), og paragraffen omvendt dækker forhånelse af andre grunde end „race“, fx tro. Bestemmelsen kriminaliserer forhånelse eller nedværdigelse af grupper, der afgrenses ved race, hudfarve, national eller etnisk oprindelse, tro eller seksuel orientering (Rigsadvokaten, 2006a: 25). I lyset af baggrunden for indførslen og ændringen af bestemmelsen (jødeforfølgelse og racediskrimination) forekommer det oplagt, at grunden hertil må være, at sådanne grupper kan være særligt forfulgte eller udsatte og derfor skal beskyttes.

\section{Blasfemiparagraffen}

„\$140. Den, der offentlig driver spot med eller forhåner noget her i landet lovligt bestående religionssamfunds troslærdomme eller gudsdyrkelse, straffes med bøde eller fængsel indtil 4 måneder.“

Til trods for det populære tilnavn omhandler blasfemiparagraffen ikke en religiøs forbrydelse. Bestemmelsen angår den offentlige orden, dvs. at dens formål er at undgå stridigheder og uroligheder pga. krænkelse af religiøse følelser, hvorfor paragraffen står i straffelovens kapitel 15 om forbrydelser mod den offentlige orden og fred (Rigsadvokaten, 2006a: 14; Koch, 2006: 74). ${ }^{6}$ Bestemmelsen beskytter ikke religiøse følelser i almindelighed eller religion som sådan.

Hvis begrundelsen angår hensynet til den offentlige orden, ville det principielt set være mest konsekvent at omformulere paragraffen til eksplicit at angå ytringer, der med overhængende sandsynlighed vil fore til offentlig uorden, da trusler mod den offentlige orden er grund til at begrænse ytringsfriheden (når det er en grund), lige gyldigt om de skyldes krænkelse af religiøse troslærdomme knyttet til lovligt bestående trossamfund eller ej. Således anskuet er henvisningen til troslærdomme og gudsdyrkelse irrelevant.

Man kan dog også forstå blasfemiparagraffens begrundelse som at beskytte bestemte udsatte grupper, nemlig religiøse mindretal, mod visse former for forhånelse og nedværdigelse, der ikke dækkes af racismeparagraffen (Koch, 2006: 76f.). Så er grunden til i givet fald at beholde blasfemiparagraffen en helt anden, end dens indhold om religiøse trossamfund og disse trossætninger og gudsdyrkelse antyder, nemlig at racismeparagraffens beskyttelse af udsatte grupper er utilstrækkelig. En mere gennemskuelig lovgivning ville derfor afskaffe blasfemiparagraffen og styrke racismeparagraffen. Men for nærværende er det afgørende, at i så fald er blasfemiparagraffen begrundet på samme måde som racismeparagraffen. Spørgsmålet er dernæst, om denne begrundelse overho- 
vedet kan retfærdiggøre begrænsninger på ytringsfriheden. Det afhænger først af, om begrundelsen for overhovedet at have ytringsfrihed til at begynde med tillader sådanne begrænsninger.

\section{Begrundelser for ytringsfriheden}

I dette afsnit skitseres tre fremtrædende typer af begrundelser for ytringsfriheden med henblik på, om de tillader den slags begrænsninger på ytringsfriheden, som racismeparagraffen er udtryk for, eller om de tværtimod medfører, at ytringsfriheden bør være absolut. ${ }^{7}$ Overordnet set vil dette blandt andet afhænge af begrundelsens struktur. I etisk teori skelnes mellem konsekventialisme, der afgør moralske spørgsmål ud fra, hvilke handlinger eller institutioner der har de bedste konsekvenser, og deontologi, der opererer med principielle restriktioner på tilladte handlinger uafhængigt af konsekvenserne. Absolutte krav eller forbud vil normalt ikke kunne begrundes konsekventialistisk, idet der næsten altid vil kunne være tilfælde, hvor konsekvenserne vil være bedre, hvis et krav eller forbud omgås, hvorimod deontologiske restriktioner enten helt ser bort fra sådanne tilfælde eller sætter tærsklen for, hvornår et krav eller forbud må omgås, meget højere.

\section{Begrundelse ud fra sandhed}

En klassisk begrundelse for ytringsfrihed er baseret på værdien af sandhed og hævder, at ytringsfrihed er nødvendig for, at sandheden kommer frem. ${ }^{8}$ Med „sandhed“ tænkes der på en egenskab ved formodninger og opfattelser, og begrundelsen antager dermed, at ytringer har en saglig funktion i diskussion og argumentation om, hvad vi skal mene. Ifølge John Stuart Mills klassiske formulering af argumentet er sandhed værdifuld som et middel til velfærd og perfektionering af mennesker, og ytringsfrihed, dvs. fraværet af retslige eller sociale hindringer for fri meningsudveksling, er nødvendig fordi: 1) Censurerede meninger kunne være sande (andet ville være at forudsætte censorens ufejlbarlighed); 2) selv fejlagtige opfattelser indeholder ofte en del sandhed; den herskende mening er sjældent hele sandheden, og resten af sandheden kan kun komme frem via sammenstød mellem modsatrettede opfattelser; 3) selv hvis den herskende mening er sand, så forfalder den til en ren fordom, hvis den ikke løbende anfægtes; og 4) sandheder, der ikke anfægtes, mister deres overbevisningskraft og evne til at påvirke personer og handlinger og forfalder til rene dogmer (Mill, 1991: 69f, jf. Schauer, 1982: 15-34; Barendt, 2005: 7-13; Alexander, 2005: 128ff.).

Der er mange problemer med sandhedsargumentet, blandt andet er det ikke oplagt, at ytringer normalt har den saglige funktion, som Mill antager (han undervurderer talens retoriske funktion, fx i politisk „spin“), om der findes „sande“ opfattelser om fx politiske spørgsmål, og om sandheden er afgørende 
for et godt liv. Her er spørgsmålet dog ikke, hvor god en begrundelse for ytringsfriheden sandhedsargumentet er, men om det tillader den type begrænsninger på ytringsfriheden, som racismeparagraffen er udtryk for.

Sandhedsargumentet medfører ikke, at ytringsfriheden skal være absolut. Fordi der er tale om en konsekventialistisk begrundelse, kræver den tværtimod øjensynlig, og tillader i hvert fald, begrænsninger, når a) uregulerede ytringer ikke er den mest effektive måde at nå frem til sandheden på (jf. regler for bevisførelse i retten og fagfællebedømmelse af videnskabelige publikationer; Alexander, 2005: 128; Barendt, 2005: 9), b) ytringer slet ikke angår sandheden, eller c) ytringer hindrer sandheden. Hate speech og fighting words hævdes ofte at falde ind under de to sidste muligheder (Brink 2001: 138-142; Cohen, 1993: 253-257). Tanken er, at nedsættende udtryk som fx „perker“ ikke har et sandhedsindhold, men blot udtrykker en negativ holdning eller i hvert fald ikke lægger op til den slags afprøvning af sandheden, som sandhedsargumentet forudsætter. Mere kontroversielt hævdes det nogle gange, at nedsættende sprogbrug ligefrem kan berøve medlemmer af udsatte grupper deres stemme (silencing), enten fordi de mister selvtilliden til at tale, eller fordi andre ikke vil lytte til dem (Sumner, 2004: 152-155).

Så sandhedsargumentet kræver for det første ikke, at ytringsfriheden skal være absolut, men kan tillade begrænsninger. For det andet kan argumentet $\mathrm{i}$ sig selv begrunde begrænsninger på ytringsfriheden for visse typer ytringer, hvis bestemte betingelser er opfyldt. Hvis truende, forhånende eller nedværdigende udsagn mod udsatte grupper enten ikke kan være sande eller bidrage til, at sandheden kommer frem, eller hvis de ligefrem forhindrer, at den kommer frem, vil sandhedsargumentet således støtte den slags begrænsninger, som racismeparagraffen er udtryk for.

\section{Begrundelser ud fra autonomi}

En umiddelbart mere overbevisende moralsk begrundelse for ytringsfriheden er baseret på værdien af autonomi, dvs. (meget groft sagt) det, at man er en agent, der træffer valg og selv bestemmer, hvordan man vil leve sit liv (Schauer, 1982: 67-72; Alexander, 2005: 68, 130ff., 134f.; Barendt, 2005: 13-18; Scanlon, 2003: 97). Ifølge deontologiske autonomibegrundelser skal statslig indgriben i personers frihed kunne begrundes på en måde, der er forenelig med respekt for dem som autonome individer, hvilket placerer en principiel restriktion på, hvilke begrundelser der er tilladelige. Ytringer må $\mathrm{fx}$ ikke begrænses for at forhindre, at tilhørere danner falske formodninger eller handler på en måde, der er skadelig for dem selv; om de gør dette, er autonome personers eget ansvar (Scanlon, 2003: 14ff., jf. Brison, 1998: 326). Hvis staten forbyder ytringer for at beskytte personer mod denne slags skade, respekterer staten ikke personers evne til selv at vurdere og tage stilling til ytringerne. Ifølge kon- 
sekventialistiske autonomibegrundelser er autonomi derimod et gode, der bør fremmes, og ytringsfriheden er begrundet, hvis den fremmer personers evne til faktisk at træffe selvstændige valg, fx ved at udsætte dem for forskellige synspunkter (Scanlon, 2003: kap. 5 og 8).

Der er dog også problemer med autonomibegrundelser. Spørgsmålet er dels, hvad autonomi præcist betyder, og hvorfor det er af værdi eller skal respekteres, dels om den antagne sammenhæng mellem ytringsfrihed og autonomi er plausibel. For nærværende er spørgsmålet blot, om autonomibegrundelser, hvis man accepterer dem, tillader begrænsninger på ytringsfriheden.

Ud fra den konsekventialistiske begrundelse er ytringsfriheden et middel til et mål og er kun begrundet, hvis regulering af ytringer ikke tjener formålet bedre. Derfor er begrænsning af ytringsfriheden tilladelig, hvis dette fremmer autonomi. Under hvilke omstændigheder, dette kunne være tilfældet, afhænger af, hvad der præcist forstås ved autonomi. Hvis autonomi fx forudsætter viden om valgmuligheder, kan regulering af ytringer være tilladt eller ligefrem påkrævet, hvis dette er nødvendigt for at forhindre misinformation, eller at mængden af information bliver uoverskuelig (Brison, 1998: 333f.). Hvis autonomi involverer rationel stillingtagen, kan autonomiargumenterne $\mathrm{fx}$ begrunde restriktioner på forhånende og nedværdigende ytringer, hvis disse ikke udtrykker grunde, der kan tages rationelt stilling til, eller påvirker deres ofre på en følelsesmæssig måde, der underminerer en rationel og distanceret holdning (Brison, 1998: 328, 335; Brink, 2001: 139). De nævnte forhold mellem ytringer og autonomi er empiriske påstande, som må vurderes som sådan. Dette gælder konsekventialistiske begrundelser, men er også relevant i forhold til deontologiske begrundelser. De udelukker bestemte former for skade som legitime grunde for at begrænse ytringer, fordi skaden hævdes at være medieret af autonome personers selvstændige stillingtagen. Men også dette argument kan vendes til en begrundelse for begrænsninger af ytringsfriheden, hvis hånende eller spottende ytringer skader ofre direkte, frem for indirekte. I så fald kan ofret ikke holdes ansvarligt for skaden, og statslig indgriben over for direkte skadelige ytringer er derfor forenelig med respekt for personers autonomi (Brison, 1998: 328).

Autonomibegrundelserne udelukker således ikke restriktioner på ytringsfriheden. Et yderligere spørgsmål, som diskuteres nedenfor, er, om forhånende og nedværdigende ytringer er tilstrækkeligt skadelige til at begrunde statslig indgriben.

\section{Begrundelser ud fra demokrati}

En mere politisk og særdeles fremtrædende begrundelse for ytringsfrihed tager udgangspunkt i demokrati og ytringsfrihedens rolle heri og findes igen $i$ forskellige former. Begrundelser ud fra demokratisk deliberation appellerer til 
et ideal om god demokratisk beslutningstagning som ikke blot værende et spørgsmål om flertalsafgørelser, kompromiser eller aggregering af forud givne præferencer, men som inkluderende offentlig debat, hvor grunde for og imod politikker artikuleres og diskuteres rationelt (Sunnstein, 1993: 18ff.). Man kan se deliberativt demokrati som af værdi, enten i sig selv eller som middel til andre værdier, dvs. at det er bedre, jo mere deliberative politiske beslutningsprocedurer er. Man kan alternativt, eller også, knytte værdien af ytringsfrihed til kravet om legitimitet. Legitimitet angår politiske beslutningers acceptabilitet ud fra en opfattelse af demokrati som et folks selvstyre, hvor beslutningstagere og den befolkning, der bindes af beslutningerne, ikke er forskellige grupper, og hvor befolkningen skal kunne acceptere beslutningerne som deres egne (Post, 2007: 73-76). Ytringsfrihed er nært knyttet til både idealet om deliberation og kravet om legitimitet, da deliberation består i offentlig debat, og legitimitet kræver, at borgere kan ytre sig for at påvirke beslutningsprocessen. Deliberationsargumenter for ytringsfrihed vil ofte være konsekventialistiske, idet de betragter ytringsfriheden som middel til deliberation. Legitimitetsargumenter kan derimod tage en deontologisk form, dvs. at enhver statslig indgriben i ytringsfriheden hævdes at underminere borgernes mulighed for at forholde sig til og påvirke den politiske beslutningsproces og dermed vil gøre selv samme statslige indgriben illegitim (Dworkin, 2006).

Når det kommer til demokratisk vedtagne begrænsninger på ytringsfriheden, er demokratiargumentet dog problematisk, da værdien af demokrati så figurerer på begge sider, både som en grund til ytringsfrihed og dermed mod begrænsninger, da ytringsfrihed antages at være en forudsætning for demokrati, og som en grund til at begrænse ytringsfriheden, fordi begrænsningen er demokratisk vedtaget (Alexander, 2005: 137; Barendt, 2005: 19). Dette angivelige „paradoks“ (Schauer, 1982: 40f.), der især plager deontologiske synspunkter, kan løses af konstitutionelle demokratiopfattelser, ifølge hvilke bestemte rettigheder er konstitutive for demokrati, men så kan disse rettigheder ikke begrundes med henvisning til demokrati.

Demokratiargumentet ikke alene tillader, men leverer faktisk grunde for, bestemte former for begrænsninger. ${ }^{9}$ Hvis demokrati indebærer deliberation, begrunder demokratiargumentet statslig regulering af ytringer på den måde, der bedst sikrer dette (Sunnstein, 1993: 34-38). Hvis bestemte typer af forhånende ytringer underminerer deliberation, er der derfor grund til at forbyde dem (Sunnstein, 1993: 192f.; Brink, 2001). Forhånende og nedværdigende ytringer kan således begrænses ifølge demokratiargumentet, hvis de underminerer kvaliteten af deliberation eller forhindrer, at deres ofre kan deltage på lige fod i den demokratiske offentlighed, der er en forudsætning for legitimitet. Sagen forekommer mere enkel for deontologiske legitimitetsargumenter, ifølge hvilke fravær af statslig indgriben i ytringsfriheden er en forudsætning for legitimi- 
tet. Men deontologiske synspunkter må så enten afvise alle begrænsninger på ytringsfrihed, også fx injurielovgivning, tavshedspligt osv., eller forklare, hvorfor nogle typer ytringer, men ikke andre, er afgørende for legitimitet. Første alternativ forekommer uacceptabelt, og den anden mulighed har den svaghed, at enhver ytring kan være „politisk“, også fx personangreb eller afsløringer af statshemmeligheder. Der vil oftest være gode grunde til alligevel at forbyde bestemte former for ytringer, selvom de kan hævdes at være „politiske“ og som sådan falde under legitimitetsargumentets restriktion, men så er restriktionen netop ikke længere absolut, men afvejes over for andre hensyn, hvilket åbner for begrænsninger. Selv hvis ytringsfriheden forstås som konstitutiv for demokrati, vil den endvidere næppe være den eneste konstitutive rettighed, og så kan konflikter imellem rettigheder begrunde begrænsninger heraf (Sumner, 2004: $73 \mathrm{ff}$.$) .$

\section{Skadesprincippet}

Selv hvis begrundelserne (der hverken er udtømmende eller gensidigt uafhængige eller udelukkende) tillader begrænsninger, er spørgsmålet stadig, om den slags ytringer, som racismeparagraffen forbyder, faktisk bør forbydes. I denne forbindelse er det nærliggende at inddrage Mills såkaldte „skadesprincip“. Ifølge princippet er indgriben over for (voksne, myndige) personers handlinger kun tilladelig, hvis de skader andre (Mill, 1991: 30f.; Feinberg, 1984: 11f.; Holtug, 2002: 363; Sumner, 2004: 20-30). Det er altså ifølge princippet ikke tilladt at gribe ind, hvis handlingen ikke er skadelig (hvilket udelukker retslig moralisme, dvs. brug af loven til at gribe ind over for angiveligt umoralske handlinger, der ikke er skadelige) eller kun skader personen selv (hvilket udelukker paternalisme). Selv hvis handlinger skader andre, er det endvidere spørgsmålet, om indgriben er nødvendig og effektiv til at modvirke skaden. Skade mod andre er en nødvendig, men ikke en tilstrækkelig betingelse for, at indgriben er acceptabel.

Skadesprincippets implikationer afhænger af, hvad man forstår ved „skade“, hvilket igen afhænger af, hvad de relevante „interesser“ er. Fortalere for skadesprincippet betragter ikke alle negative oplevelser ( $\mathrm{fx}$ skuffelse, fornærmelse, vrede) som skade, for så kan enhver handling vise sig at være skadelig, og så vil skadesprincippet potentielt begrunde omfattende indgreb frem for at sikre frihed herfra (Sumner, 2004: 47f.; jf. Holtug, 2002). Det er endvidere ikke alle tilfælde af interessekrænkelse, der begrunder indgriben, fx skader konkurrence på markedet „tabernes“ interesser, uden at dette i sig selv er grund til indgriben. Fortalere for princippet forstår derfor skade som uretmæssig frustrering af grundlæggende interesser, hvor ,grundlæggende interesser“ kun betegner tilstrækkeligt vigtige forhold for gennemsnitlige personer (Feinberg, 1984: 34ff, 49ff), og „uretmæssig“ forstås som krænkelse af rettigheder (Mill, 1991: 90, 
108f.; Feinberg, 1984: 109f.; Sumner, 2004: 28, 31f.). Bestemmelsen af, hvilke interesser der er tilstrækkeligt vigtige, og hvornår de frustreres uretmæssigt, forudsætter en mere grundlæggende moralsk teori, hvorfor skadesprincippet ikke kan være et grundlæggende princip (Holtug, 2002: 380).

Det kan forekomme uplausibelt, at skade til andre er den eneste gyldige grund til at gribe ind, hvorfor nogle accepterer, at der kan være andre grunde til indgriben, men at skade til andre er den vigtigste og tungest vejende (Feinberg, 1984: 11f.). For nærværende er det dog ikke nødvendigt at afgøre, om skadesprincippet overhovedet er plausibelt og i så fald i hvilken form. Eftersom kritikken af princippet ofte er, at det er for restriktivt, vil begrænsninger af ytringsfriheden være særlig velbegrundede, hvis de kan forsvares inden for rammerne af skadesprincippet, lige gyldigt om man i øvrigt accepterer princippet. Skadesprincippet lader desuden til at indfange dele af den indledningsvist skitserede begrundelse for racismeparagraffen som beskyttelse af udsatte grupper.

\section{Skadelige ytringer}

Spørgsmålet er derfor, om ytringer kan skade andre i en relevant forstand. Modstand mod den type begrænsninger på ytringsfriheden, som findes i racismeparagraffen, begrundes nogle gange med, at ytringer ikke kan skade. Men faktisk understøtter skadesprincippet ikke denne indvending, i hvert fald ikke i Mills eller, kan man argumentere for, i nogen tilnærmelsesvis plausibel version. Som klasse af handlinger opfylder ytringer skadesprincippets betingelser for indgriben, nemlig at de skal være other regarding eller sociale, dvs. at de ikke falder ind under princippets absolutte restriktion mod regulering af self regarding eller individuelle handlinger. At ytringer kan skade andre, kan forekomme mærkværdigt; man kan jo ikke slå sig på ord. Men ytringer kan være dårlige for folk på en lige så vigtig måde som fysisk skade. Det afgørende er ikke, om man lider fysisk skade, men at ytringer kan frustrere interesser ligesom fysisk skade. Mills forsvar for ytringsfriheden er derfor ikke baseret på, at ytringer ikke kan skade (Sumner, 2004: 24f.), hvilket mere generelt også er et uplausibelt synspunkt (Schauer, 1993; Cohen, 1993: 219; Fish, 1994: 105ff.; Scanlon, 2003: 8-12).

Fordi ytringer kan skade andre, må begrundelsen for ytringsfriheden i stedet baseres på de forventelige gode konsekvenser heraf. Det betyder samtidig, at dårlige konsekvenser af bestemte typer ytringer kan tale for begrænsning af ytringsfriheden (Sumner, 2004: 26ff.). Så spørgsmålet er, om den slags ytringer, som racismeparagraffen forbyder - „offentligt fremsatte udsagn, der truer, forhåner eller nedværdiger personer pga. deres race, hudfarve, nationale eller etniske oprindelse, tro eller seksuelle orientering“ - kan skade andre. Der er overordnet set to muligheder: Enten er en ytring indirekte skadelig, fx for den 
opildner tilhørere til at begå vold eller diskriminere mod medlemmer af en gruppe, eller direkte skadelig, dvs. at selve ytringen skader medlemmer af gruppen (Sumner, 2004: 159; Cohen 1993: 231f.; Scanlon, 2003: 11f.). For at man kan tale om indirekte skade, skal ytringen være årsag til tilhørernes skadelige handlinger i en relevant forstand, og (noget af) ansvaret herfor skal desuden kunne placeres hos taleren. Disse empiriske og moralske betingelser for, at ytringer kan være indirekte skadelige i en relevant forstand, rejser komplicerede principielle og praktiske spørgsmål, der ikke kan behandles nærmere her.

Med hensyn til direkte skade forekommer det rimeligt, at trusler kan have negative psykologiske følger $\mathrm{i}$ form af, at stress og frygt og forhånende og nedværdigende ytringer kan hævdes at forårsage negative psykologiske tilstande som manglende selvrespekt (Sumner, 2004: 159f.). Negative psykologiske følger af trusler, forhånelse og nedværdigelse tæller kun som skade, hvis de uretmæssigt frustrerer interesser. Det kan de dog gøre ved at påvirke ofrenes handlinger på negative måder, $\mathrm{fx}$ at ofrene undgår bestemte sociale sammenhænge eller at gøre brug af valgmuligheder eller rettigheder. Hvis dette medfører, at ofrene hindres $i$ at forfølge deres grundlæggende interesser, er der tale om skade ifølge skadesprincippet. Selvom skaden er direkte, er den instrumentel, dvs. at den opstår via de nævnte kausale effekter på fx selvrespekt, der i sig selv er skadelige (Sumner, 2004: 146).

Direkte instrumentel skade rejser dels et empirisk spørgsmål, om de antagne kausale sammenhænge holder, dels et moralsk om, hvornår personer selv kan holdes ansvarlige for evt. lav selvrespekt og følgerne heraf. Det hævdes nogle gange, at ansvaret for sådanne negative konsekvenser ikke kan tilskrives ytringerne, da de er medierede af offerets egne holdninger og autonome stillingtagen. Dette er dog ofte et problematisk synspunkt af flere grunde. Nogle følger af sådanne ytringer, fx angst, er ikke medierede. Omvendt er fysisk smerte også medieret på måder, som ikke nødvendigvis er relevant forskellige, uden at man dermed holder ofre ansvarlige herfor (Schauer, 1993). Og selv når de negative konsekvenser skyldes, at ofret for ytringerne har taget autonomt stilling til fx trusler, kan ansvaret for det ændrede handlingsmønster kun tilskrives offeret, hvis de medierende formodninger og holdninger er urimelige og let kan ændres, hvilket ikke nødvendigvis er tilfældet.

Forhånelse og nedværdigelse kan også forstås som værende dårlig i sig selv, uafhængigt af evt. psykologiske følger. Problemet antages nogle gange at være, at der hermed fremsættes falske beskrivelser af en gruppe, fx at sorte er mindre intelligente, at kvinder er sexobjekter, eller at muslimer er terrorister. Det er dog problematisk at forstå forhånelse sådan, fordi det forekommer muligt at fremsætte falske udsagn på måder, der ikke er forhånende eller nedværdigende. Desuden rejser dette spørgsmålet, om forhånende og nedværdigende udsagn kan være sande. Forhånelse og nedværdigelse hævdes derfor alternativt ofte 
udelukkende at være et spørgsmål om måden, noget siges på. ${ }^{10}$ Dette er dog også problematisk, da det ofte (tænk fx på Muhammedtegningerne) ikke er klart, hvad der er et udsagns indhold (det udtrykte synspunkt), og hvad der er måden, det ytres på (Jones, 1980: 141-144; 1990: 434f.). En mere plausibel, om end kontroversiel, mulighed er, at forhånelse og nedværdigelse hverken består i udsagns form alene eller er faktuelle udsagn, der kan være sande eller falske i en ligefrem forstand, men er værdiudsagn om, at medlemmer af en bestemt gruppe er mindre værd end andre.

Sammenfattende kan trusler, forhånelser og nedværdigelser godt være skadelige ifølge skadesprincippet, så princippet udelukker ikke begrænsninger på denne slags ytringer. Både direkte og indirekte skade er dog problematiske som begrundelser for den slags begrænsninger, der findes i racismeparagraffen, fordi bestemmelsen kriminaliserer alle truende, forhånende eller nedværdigende ytringer, lige gyldigt om de faktisk er skadelige (Sumner, 2004: 193). Dette kunne skyldes, at lovbestemmelser af praktiske grunde må være bredt formulerede, hvorfor racismeparagraffen er begrundet, hvis tilstrækkeligt mange forhånende og nedværdigende ytringer er skadelige. Dette rejser dog dels spørgsmålet, hvorvidt tilstrækkeligt mange sådanne ytringer faktisk er skadelige, og hvilken andel, der er tilstrækkelig. Dels indebærer generalitetssynspunktet, at bestemmelsen i en del tilfælde vil kriminalisere ytringer, der ikke er skadelige, hvilket mange vil betragte som problematisk. Det er derfor værd at undersøge, om man kan give en mere principiel begrundelse for bestemmelsen. Desuden forklarer denne begrundelse for racismeparagraffen ikke, hvorfor forhånende og nedværdigende ytringer så kun skal kriminaliseres, når de angår race, hudfarve, national eller etnisk oprindelse, tro eller seksuel orientering (Sumner, 2004: 195). Der forekommer derfor at være behov for en bredere og mere præcis begrundelse, hvis denne slags begrænsninger af ytringsfriheden skal retfærdiggøres.

\section{Ligeværd for minoriteter}

En begrundelse af racismeparagraffen skal kunne forklare, dels hvorfor der er grund til at begrænse forhånende og nedværdigende ytringer, dels hvorfor der kun er det, når de angår medlemmer af grupper afgrænset ud fra „race, hudfarve, national eller etnisk oprindelse, tro eller seksuel orientering". Det indledningsvist skitserede rationale for racismeparagraffen (og måske blasfemiparagraffen) som beskyttelse af særligt udsatte grupper rejser spørgsmålet, hvad der karakteriserer sådanne grupper. Fokus er især på forhånende og nedværdigende ytringer forstået som udsagn om, at medlemmer af disse grupper har lavere værdi eller status, og der antages ikke at være grund til at begrænse sådanne udsagn, når de angår medlemmer af andre grupper. Problemet med forhånelser og nedværdigelser pga. en persons hudfarve eller religion kan der- 
for ikke skyldes træk ved sådanne ytringer isoleret betragtet, men må forklares kontekstuelt ved, at træk som hudfarve og religion i en given sammenhæng er relevant forskellige fra andre måder at afgrænse grupper på. Og hvis forhånelse og nedværdigelse ikke bør forstås som faktuelle domme, men som værdiudsagn, må denne forskel mellem fx hudfarve og religion på den ene side og træk som fx politisk observans og indkomst på den anden angå værdi eller status frem for empiriske egenskaber. Den relevante forskel mellem forhånelse og nedværdigelse af personer pga. deres hudfarve eller religion og pga., at de er skaldede eller går til spejder, kunne derfor oplagt være, at hudfarve og religion, modsat hovedbehåring eller fritidsinteresser, i en bestemt social sammenhæng i højere grad forbindes med social værdi og status.

Selvom denne forståelse af forhånelse og nedværdigelse peger på en forskel, der kan forklare racismeparagraffens fokus på forhånelse af bestemte grunde, er spørgsmålet stadig, om forskellen begrunder begrænsning af disse ytringer. Forskellen kan styrke begrundelsen baseret på skadesprincippet, idet den måske kan forklare, hvorfor trusler, forhånelser og nedværdigelser pga. de nævnte træk er mere skadelige end trusler, forhånelser og nedværdigelser pga. andre træk. Men ifølge skadesprincippet kan forhånende og nedværdigende ytringer kun begrænses, hvis de forårsager skade eller i sig selv er skadelige. Selvom sådanne ytringer kan forårsage skade, er problemet stadig, at ikke alle sådanne ytringer gør det, hvorfor racismeparagraffen ifølge princippet er for bred. $\mathrm{Og}$ definitionen af „skade“ som uretmæssig frustrering af grundlæggende interesser udelukker, at man har en interesse i at undgå forhånende og nedværdigende ytringer, og dermed at de i sig selv kan være skadelige. En alternativ begrundelse må derfor forklare, hvorfor forhånelse og nedværdigelse mod bestemte grupper kan være moralsk problematisk, på en måde som i tilstrækkeligt grove tilfælde begrunder begrænsning af sådanne ytringer, uanset om de er skadelige i skadesprincippets forstand. Om en sådan begrundelse formuleres som en revision af skadesprincippets krav til, hvad der tæller som grundlæggende interesser, eller som et alternativ til princippet, er mindre vigtigt.

En sådan begrundelse, der forekommer at indfange den indledningsvist skitserede rationale for racismeparagraffen, er baseret på et politisk ideal om at sikre lighed som ligeværdighed eller lige status mellem alle medlemmer af samfundet uanset gruppetilhørsforhold, koblet med en samfundsteoretisk forståelse af, at bestemte grupper er minoriteter i den forstand, at de ikke blot er i mindretal eller generelt dårligere stillede end majoriteten, men ekskluderede fra statusfællesskabet eller nægtet ligeværdighed af det omgivende samfund (Galeotti, 2002: 88-91). „Ligeværd“ og „lige status“ betegner her ikke den formelle status, der knytter sig til statsborgerskab, eller de lige rettigheder, der følger heraf, men den moralske lighed, som principielle argumenter for lige rettigheder tager udgangspunkt i. Moralsk lighed eller status hævdes traditio- 
nelt af kantianere og liberale af forskellige slags at angå personer, ikke disses holdninger eller handlinger (Rawls, 1993: 29-35). Accept af en person som ligeværdig kan således ikke kræve, at man er enig i vedkommendes holdninger eller finder vedkommendes måde at leve på værdifuld. En begrundelse af racismeparagraffen ud fra ligeværd forudsætter samtidig, at ligeværd kan være på spil i situationer, der ikke handler om forskelle i rettigheder eller diskrimination, og hvor folk ikke bliver skadet i skadesprincippets forstand. Ligeværd er derfor et mere diffust socialt forhold, der ofte debatteres som et spørgsmål om „anerkendelse“ (Lægaard, 2005; 2007a). Spørgsmålet er, dels om anerkendelse af ligeværd kan være et retsligt anliggende (frem for et rent socialt spørgsmål), dels om ligeværd kan forstås på en måde, der er bred nok til at begrunde racismeparagraffen, uden at indebære at enhver kritik af andres holdninger eller handlinger er udtryk for forhånelse?

En begrundelse for begrænsninger af forhånende og nedværdigende ytringer ud fra ligeværd går ud fra en påstand om, at sådanne ytringer benægter ligeværd. Dette er hverken en kausal eller en normativ påstand, men en konstitutiv, dvs. at ligeværd er et spørgsmål om en bestemt slags (social, moralsk, politisk) status, og forhånelse og nedværdigelse defineres som ytringer, der benægter ligeværd. Hvis benægtelse af ligeværd er moralsk dårlig, i sig selv og/ eller instrumentelt, er der en grund til at begrænse alle forhånende og nedværdigende ytringer. Spørgsmålet er så, dels hvorfor benægtelse af ligeværd skulle være moralsk dårlig, dels om den resulterende grund er tungtvejende nok til at retfærdiggøre begrænsninger som racismeparagraffen.

Den normative påstand er begrundet, hvis dens implikationer i forskellige henseender stemmer godt med vores velovervejede intuitioner om, hvordan man bør behandle hinanden. Så er det afgørende, at et ideal om ligeværd faktisk lader til at nyde bred accept i mange sammenhænge (Galeotti, 2002: 150). Men selv da forklarer en sådan „kohærentistisk“ begrundelse stadig ikke, hvorfor forhånelse $\mathrm{og}$ nedværdigelse kun er dårlig rettet mod bestemte grupper. Man kan derfor alternativt eller supplerende forsøge at udlede idealet af andre normative synspunkter, der forekommer mere sikre.

En sådan begrundelse kunne baseres på en påstand om, at benægtelse af ligeværdighed skader personer, dvs. en kausal sammenhæng (Galeotti, 2002: 96ff.). Sammenhængen kunne $\mathrm{fx}$ bestå i, at personers mulighed for at forfølge deres interesser forudsætter selvrespekt, og at selvrespekt understøttes af ligeværd og undermineres af forhånelse og nedværdigelse (Lægaard, 2005). En sådan instrumentel begrundelse kan potentielt forklare forskellen mellem forhånelse pga. hudfarve og tøjsmag, men ligesom i begrundelsen ud fra skadesprincippet er den kausale påstand ikke plausibel i alle tilfælde. Dette ændrer sig dog, hvis ligeværdighed er en form for non-excludable public good, dvs. at man kun kan sikre ligeværd for nogen ved at sikre det for alle. Dette ville 
udgøre en forskel til den slags interesser, som skadesprincippet opererer med, der er excludable private goods, da man fx godt kan beskytte en person mod fysisk skade eller røveri uden at beskytte alle. Denne forskel kunne skyldes, at ligeværd er et træk ved den sociale virelighed i et samfund, ligesom trafiksikkerhed eller ren luft er ved den fysiske virkelighed, hvorimod fysisk overlast er en egenskab ved individuelle kroppe. Et andet problem er, at folk kan have lav selvrespekt af grunde, der ikke har med manglende anerkendelse af ligeværd at gøre. Begrundelsen kan derfor ikke omhandle lav selvrespekt generelt, da dette kunne medføre begrænsninger af ytringer, der ikke benægter ligeværd, men fx blot udtrykker uenighed i religiøse trossætninger.

Hvis man kan specificere begrebet om ligeværd på en plausibel måde, og benægtelse heraf faktisk er moralsk dårlig, er der en grund til at begrænse forhånende og nedværdigende ytringer. Om denne grund vejer tungt nok til at retfærdiggøre en begrænsning af ytringsfriheden, afhænger af to faktorer: a) Hvor vigtigt idealet om ligeværd er, og b) hvor meget ytringsfriheden begrænses for at beskytte ligeværd. Idealet skal være meget vigtigt for at begrunde omfattende begrænsninger, hvorimod marginale begrænsninger ofte kan begrundes, selv hvis ligeværd ikke er det vigtigste politiske hensyn. I denne forbindelse er det interessant, at racismeparagraffen og blasfemiparagraffen kun forbyder forhånelser og nedværdigelser af en vis grovhed (Rigsadvokaten, 2006a: 15, 25; IFM, 2006). Samtidig kræver racismeparagraffen ikke, at medlemmer af den forhånede eller nedværdigede gruppe faktisk har fået kendskab til eller følt sig truet, forhånet eller nedværdiget af ytringen. Bestemmelsen kræver i stedet en objektiv vurdering af, om ytringen i den konkrete sammenhæng kan anses som egnet til at fremkalde frygt eller følelser af forhånelse eller nedværdigelse (Rigsadvokaten, 2006a: 20f.; IFM, 2006). Grovhedskriteriet sikrer, at begrænsningen af ytringsfriheden ikke bliver for omfattende, og objektivitetskravet antyder, at det ikke er ytringernes direkte påvirkning af enkeltindivider, der er afgørende. Disse træk kan forklares af ligeværdsbegrundelsen og samtidig løse noget af problematikken om graden af begrænsning af ytringsfriheden over for vigtigheden af ligeværd.

Selv hvis begrundelsen for retslig begrænsning af forhånende og nedværdigende ytringer er, at de underminerer ligeværd, er den mest effektive måde at modvirke dette på ikke nødvendigvis at retsforfølge alle forhånende og nedværdigende ytringer. Dette forekommer urimeligt, både af praktiske hensyn og fordi det ville være en markant begrænsning af ytringsfriheden. Hvis ligeværd handler om den generelle status, medlemmer af forskellige grupper nyder, er enkeltytringer eller retsforfølgelse heraf ikke nødvendigvis de vigtigste faktorer for, om der er statuslighed i et samfund. Det er givetvis mere afgørende, om staten signalerer, at alle har lige status, og at forhånelser og nedværdigelser er uacceptable, end om den forfølger enhver ytring, der anfægter lige- 
værd. En måde at signalere dette på, der tages alvorligt og ikke bare som tom snak, er at forbyde forhånende og nedværdigende ytringer. Denne slags lovgivning kan have den nævnte symbolske effekt, uafhængig af om den faktisk fører til mange sager (Galeotti, 2002: 149, 156). I så fald leverer hensynet til ligeværd en begrundelse for racismeparagraffen, som på den ene side forklarer, at kun grove forhånelser og nedværdigelser skal forbydes (da det primære formål er den symbolske bekræftelse af minoritetsmedlemmers ligeværd), og dermed på den anden side nedbringer omfanget af den retslige begrænsning af ytringsfriheden, hvilket gør begrænsningen lettere at retfærdiggøre.

Selvom den retslige begrænsning af ytringsfriheden ikke er så omfattende, kan ytringsfriheden være truet af andre grunde. En standardindvending mod forbud mod bate speech er, at de kan antages at medfore en chilling effect på politisk debat, selv hvis de kun forbyder udvalgte typer af særligt grove ytringer (Sumner, 2004: 183; Cohen, 1993: 233; Barendt, 2005: 32). Hvis formålet med et forbud er at signalere officiel afstandtagen til forhånende og nedværdigende ytringer, er en vis chilling effect dog ikke en uvelkommen sideeffekt, men den primære hensigt, da ligeværd netop ikke søges sikret via retsforfølgelse af enkeltytringer, men via generel symbolsk afstandtagen. Spørgsmålet er da i stedet, om denne dæmper på debatten risikerer at sprede sig fra faktiske forhånelser og nedværdigelser til andre typer ytringer, og om det er tilstrækkeligt klart og politisk ukontroversielt, hvad der udgør forhånelse og nedværdigelse. Indvendingen viser vigtigheden af en klar offentlig tilkendegivelse af, hvad der betragtes som forhånelse og nedværdigelse, og hvad begrundelsen er for at forbyde sådanne ytringer. Begrænsningen bør ikke være en rent juridisk spidsfindighed, da det så på den ene side ikke er sikkert, at den vil have den symbolske effekt, og den på den anden side kan medføre en for omfattende selvcensur.

Et andet øjensynligt problem med ligeværdsbegrundelsen for racismeparagraffen er, at bestemmelsen angår alle forhånende og nedværdigende udsagn pga. de nævnte træk, lige gyldigt om de er rettet mod medlemmer af majoriteten eller minoriteter. Dette er der en god juridisk forklaring på, nemlig at andet ville være en form for diskrimination, men hvis formålet kun er beskyttelse af minoriteter, forekommer bestemmelsen stadig at være for bred. Ligeværdsbegrundelsen er dog ikke uforenelig med den ikke-diskriminerende formulering af paragrafferne; tværtimod kan den siges at lægge op hertil, da formålet er at signalere lighed. Selvom racismeparagraffen gælder for alle, kriminaliserer den ikke desto mindre kun forhånelse og nedværdigelse pga. bestemte træk, der traditionelt har været tættest knyttet til statusforskelle. Hvis formålet med bestemmelsen er at udrydde denne slags statusforskelle, giver det god mening generelt at forbyde forhånende og nedværdigende ytringer af disse grunde, lige gyldigt hvem de rettes mod, da alle sådanne ytringer kan 
antages at opretholde sammenknytningen af $\mathrm{fx}$ hudfarve og værdighed. Der er endvidere ikke grund til at tro, at der vil blive rejst mange sager om ytringer mod majoriteten, og grovhedskriteriet kunne desuden tage hensyn til, om ytringer er rettede mod personer, der tilhører en udsat gruppe. Det er dog afgørende, at et sådant gradueret grovhedskriterium stadig er objektivt, så det ikke bliver op til folk selv at afgøre, om de er udsat for forhånelse.

Ligeværdsargumentet leverer en begrundelse for racismeparagraffen, der dels har en vis plausibilitet (om end den ikke er uden problemer), dels indfanger den officielle motivation for racismeparagraffen, dels forklarer den form, forbuddet mod forhånelser og nedværdigelser har i bestemmelsen. Begrundelsen er på de sidste punkter mere succesfuld end skadesprincippet, men begrundelserne udelukker ikke hinanden. Ligesom for ytringsfriheden generelt er den mest plausible begrundelse for begrænsninger af ytringsfriheden pluralistisk.

\section{Afslutning: ytringsfriheden og Muhammedtegningerne}

Hvad vil ovenstående begrundelser for ytringsfriheden og racismeparagraffen medføre for den konkrete sag om Muhammedtegningerne? Som nævnt er et fremtrædende synspunkt i sagen, nemlig ideen om den absolutte ytringsfrihed, uholdbart både med hensyn til positiv ret og ud fra de bedste moralske begrundelser. Et andet synspunkt, nemlig at muslimer „gør krav på en særstilling, når de insisterer på særlig hensyntagen til egne religiøse følelser" (Rose, 2005), er også fejlagtigt både med hensyn til positiv ret, hvor blasfemiparagraffen faktisk beskytter visse religiøse følelser, og i forhold til begrundelser for begrænsninger på ytringsfriheden ud fra skade eller ligeværd, der har karakter af generelle principper.

Modsat er det blevet hævdet, at Fyllands-Posten med forsæt ville forhåne, hvilket udgør et i sig selv strafbart „forsøg“ (Thorsen, 2006: 83, 89; se dog IFM, 2006). Denne fortolkning af Fyllands-Postens begrundelse for at trykke tegningerne er dog problematisk. Den officielle begrundelse for at bestille og trykke tegningerne var ikke at håne eller fornærme muslimer. Flemming Rose skrev eksplicit, at hån, spot og latterliggørelse ikke altid er „lige sympatisk og pænt at se på“, og benægtede, ,at religiøse følelser for enhver pris skal gøres til grin“ (Rose, 2005). Bestillingen gik desuden ikke på karikaturer, men på tegninger af Muhammed „som de [tegnerne] ser ham.“ At der skulle foreligge forsøg på at forhåne, kan således ikke begrundes ud fra teksten.

Ud fra begrundelserne for begrænsning af ytringsfriheden er der flere problemer med rigsadvokatens behandling af klagerne mod Fyllands-Posten. Rigsadvokaten antog blandt andet, at krænkelsen angik islams interne billedforbud, og afviste denne klage med begrundelsen, at der ikke kan siges at gælde et generelt og absolut forbud mod at tegne profeten Muhammed i islams tros- 
lærdom (Rigsadvokaten, 2006b: 6). Problemet er, at selv hvis der gjaldt et sådant forbud internt $\mathrm{i}$ islam, burde det ikke kunne danne grundlag for et statsligt forbud mod, at ikke-troende tegner Muhammed. For så vidt at blasfemiparagraffen medfører dette, kan den ikke retfærdiggøres ud fra nogen af de her diskuterede begrundelser. Hvis den fx er begrundet som en beskyttelse af udsatte religiøse minoriteter, bør den ikke beskytte disses troslærdomme, men gruppens ligeværd.

Rigsadvokatens primære grund til ikke at rejse sag mod Fyllands-Posten ud fra racismeparagraffen var, dels at det er tvivlsomt, om tegningerne forhåner Muhammed, dels at forhånelse af Muhammed ikke indebærer forhånelse af muslimer generelt (Rigsadvokaten, 2006b: 9; jf. Koch, 2006: 79; Thorsen, 2006: 87-90). Hvis begrundelsen for begrænsningen af ytringsfriheden angår skade eller ligeværd, er det afgørende derimod, om der er tale om en velafgrænset gruppe. Da Muhammed både for muslimer og ikke-muslimer forbindes med muslimer, forekommer Rigsadvokatens begrundelse på denne baggrund urigtig og som en måde at undgå at konfrontere det egentlige spørgsmål på, nemlig om tegningerne er så grove, at de skader muslimer eller underminerer deres ligeværd, og om de er det på en måde, der opvejer modsatrettede hensyn. På disse punkter er Rigsadvokatens vurdering derimod rimelig, nemlig at tegningerne med enkelte mulige undtagelser slet ikke er forhånende eller nedværdigende. Undtagelserne (især bomben i turbanen) angår associationer til terrorisme og kvindeundertrykkelse, men kan lige så vel fortolkes som en kritik af forsøg på at begrunde disse ting i islams navn (Rigsadvokaten, 2006b: 6f., 9). Selv fortolket som kritik af islam er det dog spørgsmålet, om disse tegninger virkelig er så grove, at de skader muslimer (Lægaard, 2007b). Og selv hvis de gjorde, er der tungtvejende grunde til ikke at begrænse en sådan kritik, for så vidt at den angår forkastelige handlinger, der rent faktisk finder sted.

Med hensyn til muslimers ligeværd er det afgørende at skelne mellem lige værdighed eller status på den ene side og accept af holdninger eller handlinger på den anden. I et liberalt pluralistisk samfund kan man kræve ligeværdighed, men kun tolerance over for anderledes synspunkter, ikke accept heraf (Jones, 1990; Lægaard, 2007a). Derfor kan ligeværd ikke begrunde et forbud mod kritik af muslimers religion eller livsformer. Set i dette lys er tegningerne heller ikke grove, og kritik og satire kan tværtimod være (men er ikke nødvendigvis) udtryk for behandling af muslimer som ligeværdige medborgere. Det er afslutningsvis en mulighed, at hele affæren har haft nogle positive konsekvenser for danske muslimers status, $\mathrm{fx}$ en bredere anerkendelse af, at „demokratiske muslimer" ikke er en selvmodsigelse, og en forståelse af de store forskelle blandt muslimer, der kan bidrage til, at muslimer ikke altid behandles som en udifferentieret gruppe. 


\section{Noter}

1. Tidligere versioner af denne artikel blev præsenteret på Center for studier af lighed og multikulturalismes konference om Kulturel Diversitet og ved et møde i nyt retsfilosofisk netværk i September 2007. Tak til Isak Winkel Holm, Mihail Larsen, Kasper Lippert-Rasmussen, Søren Flinch Midtgaard, Birgitte Kofod Olsen, Henrik Palmer Olsen, Thomas Søbirk Petersen, Christian Rostbøll og Jesper Ryberg for kommentarer og til Carlsbergfondet for finansiel støtte.

2. Den Europæiske Menneskerettighedskonvention (EMRK) og FN's konvention om borgerlige og politiske rettigheder er lige så vigtige for de retslige grænser for ytringsfriheden som dansk lovgivning (IFM, 2006; Rigsadvokaten, 2006a: 26-30; Thorsen, 2006: 80). Denne artikel fokuserer på dansk lov, da der endnu ikke er fældet dom ved den Europæiske Menneskerettighedsdomstol (EMD) om Muhammedtegningerne, hvorfor debatten har været fokuseret på de danske bestemmelser, der endvidere blot bruges som eksempel på en bestemt type begrænsninger af ytringsfriheden.

3. Lovforslag L 103, folketingsåret 2001-02, 2. samling, og L 131 fra folketingsåret 2004-05, 2. samling.

4. L 88 (om $\$ 140$ ), fremsat 28.11.2006, forkastet ved tredjebehandling 15.05.2007; L 103 (om \$266 b), fremsat 07.12.2006, stadig under behandling i skrivende stund, se: http://www.ft.dk/Samling/20061/lovforslag/L103/index.htm

5. Givet at alt, der ikke er forbudt, er tilladt (Feinberg, 1984: 8f.), er det bemærkelsesværdigt, at den danske grundlov stort set ikke sikrer en sådan særlig beskyttelse af ytringer, da den blot kræver, at begrænsninger skal vedtages ved lov (den „formelle“ ytringsfrihed). Dette er en markant forskel til især De Forenede Staters forfatnings First Amendment, ifølge hvilken „,congress shall make no law ... abridging freedom of speech, or of the press". I Danmark sikres ytringsfriheden derfor ikke af grundloven, men især af EMRK, artikel 10. Dennes stk. 2 tillader ligesom grundloven, og modsat the First Amendment, begrænsninger af ytringsfriheden vedtaget ved lov, men kræver, modsat grundloven, at sådanne begrænsninger skal være „nødvendige $i$ et demokratisk samfund af hensyn til den nationale sikkerhed, territorial integritet eller offentlig sikkerhed, for at forebygge uorden og forbrydelse, for at beskytte sundheden eller sædeligheden, for at beskytte andres gode navn og rygte og rettigheder, for at forhindre udspredelse af fortrolige oplysninger, eller for at sikre domsmagtens autoritet og upartiskhed." Både begrundelsen og nødvendigheden (proportionaliteten) af begrænsninger kan gøres til genstand for domstolsprøvelse, i sidste instans ved EMD. Herved sikres ytringer mod nogle typer begrænsninger, selv vedtaget ved lov (den „materielle“ ytringsfrihed).

6. Se også talerne af justitsministeren og Birthe Rønn Hornbech ved førstebehandlingen af L 88, 27.02.2007: http://www.ft.dk/Samling/20061/lovforslag/L88/ index.htm

7. Som fx hævdet af Jesper Langballe i folketingsdebatten 27.02.2007 om blasfemiparagraffen (L 88).

8. Den oprindelige version af $₫ 266$ b fra 1939 omhandlede således blandt andet ,falske rygter og beskyldninger" (Rigsadvokaten, 2006a: 17). Og ifølge Dansk Folkepartis nævnte ændringsforslag (L 103, fra 2006) skal en forhånende og nedværdigende ytring være „straffri uanset sin form, såfremt den er sand eller fremsætteren havde rimelig grund til at anse den som dækkende for de faktiske forhold“. Begge dele er spørgsmål om ytringers sandhed.

9. Jf. at EMRK art. 10, stk. 2, tillader begrænsninger af ytringsfriheden, der er „nødvendige i et demokratisk samfund“.

10. For synspunkter på både sandhed og „måde“, se talerne ved førstebehandlingen (27.02.2007) af L 103. 


\section{Litteratur}

Alexander, Larry (2005). Is There a Right of Freedom of Expression?, Cambridge: Cambridge University Press.

Barendt, Eric (2005). Freedom of Speech, 2nd ed., Oxford: Oxford University Press.

Brink, David (2001). „Millian Principles, Freedom of Speech and Hate Speech“, Legal Theory, Vol. 7, No. 2, pp. 119-157.

Brison, Susan J. (1998). „The Autonomy Defense of Free Speech“, Ethics, Vol. 108, No. 2, pp. 312-339.

Cohen, Joshua (1993). „Freedom of Expression“, Philosophy and Public Affairs, Vol. 22, No. 3, pp. 207-263.

Dworkin, Ronald (2006). „The Right to Ridicule“, New York Review of Books, Vol. 53, No. 5, p. 44.

Feinberg, Joel (1984). The Moral Limits of the Criminal Law Vol. One: Harm to Others, Oxford: Oxford University Press.

Fish, Stanley (1994). There's No Such Thing as Free Speech, and It's a Good Thing, Too, New York: Oxford University Press.

Galeotti, Anna Elisabetta (2002). Toleration as Recognition, Cambridge: Cambridge University Press.

Holtug, Nils (2002). „The Harm Principle“, Ethical Theory and Moral Practice, Vol. 5, No. 4, pp. 357-389.

IFM [Institut for menneskerettigheder] (2006). „Notat om ytringsfrihed - med udgangspunkt i Jyllandspostens Muhammed tegninger“ (n06_73), findes på: http:// humanrights.palermo.magenta-aps.dk/hoeringssvar/notat2006/hoeringssvar/

Jones, Peter (1980). „Blasphemy, Offensiveness and Law“, British Fournal of Political Science, Vol. 10, No. 2, pp. 129-148.

Jones, Peter (1990). „Respecting Beliefs and Rebuking Rushdie“, British Fournal of Political Science, Vol. 20, No. 4, pp. 415-437.

Koch, Henning (2006). „Ytringsfrihed og tro“, pp. 72-88 i Lisbet Christoffersen (red.), Gudebilleder: Ytringsfribed og tro i en globaliseret verden, København: Tiderne Skifter.

Lægaard, Sune (2005). „On the Prospects for a Liberal Theory of Recognition“, Res Publica, Vol. 11, No. 4, pp. 325-348.

Lægaard, Sune (2007a). „The Cartoon Controversy as a Case of Multicultural Recognition“, Contemporary Politics, Vol. 13, No. 2, pp. 147-164.

Lægaard, Sune (2007b). „The Cartoon Controversy: Offence, Identity, Oppression?“", Political Studies, Vol. 55, No. 3, pp. 481-498.

Mill, John Stuart (1991). On Liberty in Focus, edited by John Gray and G.W. Smith, London: Routledge.

Post, Robert (2007). „Religion and Freedom of Speech: Portraits of Mohammad“, Constellations, Vol. 14, No. 1, pp. 72-90.

Rawls, John (1993). Political Liberalism, New York: Columbia University Press.

Rigsadvokaten (2006a). „Relevante Retsregler“, findes på: http://www.rigsadvokaten.dk/ ref.aspx?id=891

Rigsadvokaten (2006b). „Afgørelse om evt. strafforfølgning i sagen om Fyllands-Postens artikel 'Muhammeds ansigt'“, findes på: http://www.rigsadvokaten.dk/ref.aspx? id $=889$

Rose, Flemming (2005). „Muhammeds ansigt“, Fyllands-Posten, 30.09, Kulturweekend, p. 3.

Scanlon, Thomas M. (2003). The Difficulty of Tolerance, Cambridge: Cambridge University Press.

Schauer, Frederick (1982). Free Speech: A Philosophical Inquiry, Cambridge: Cambridge University Press. 
Schauer, Frederick (1993). „The Phenomenology of Speech and Harm“, Ethics, Vol. 103 , No. 4, pp. 635-653.

Sumner, Leonard Wayne (2004). The Hateful and the Obscene: Studies in the Limits of Free Expression, Toronto: University of Toronto Press.

Sunnstein, Cass R. (1993). Democracy and the Problem of Free Speech, New York: The Free Press.

Thorsen, Sune Skadegård (2006). „Muhammedkrisen - symptom på en syg stat“", pp. 78-105 i Henning Nielsen, Jesper Gronenberg og Thomas Bech Madsen (red.), Verden i forandring $I X$, Odense: Syddansk Universitetsforlag. 